\title{
Alterations on peripheral B cell subsets following an acute uncomplicated clinical malaria infection in children
} Amolo S Asito1,2, Ann M Moormann³, Chelimo Kiprotich², Zipporah W Ng'ang'a1, Robert Ploutz-Snyder ${ }^{4,6}$ and Rosemary Rochford ${ }^{* 5}$

\begin{abstract}
Address: ${ }^{1}$ School of Pure and Applied Science, Kenyatta University, Nairobi, Kenya, ${ }^{2}$ Kenya Medical Research Institute, Center for Global Health Research, Kisumu, Kenya, ${ }^{3}$ Center for Global Health and Diseases, Case Western Reserve University, Cleveland, OH, USA, ${ }^{4}$ Center for Outcomes Research and Evaluation, SUNY Upstate Medical University, Syracuse, NY, USA, ${ }^{5}$ Department of Microbiology and Immunology, SUNY Upstate Medical University, Syracuse, NY, USA and ${ }^{6}$ Biostatistics Lab, Human Adaptation and Countermeasures Division, National Aeronautics and Space Administration, Houston, TX, USA

Email: Amolo S Asito - aamolo@kisian.mimcom.net; Ann M Moormann - moorms@case.edu; Chelimo Kiprotich - kchelimo@kisian.mimcom.net; Zipporah W Ng'ang'a - zipnganga@yahoo.com; Robert Ploutz-Snyder - robert.ploutzsnyder-1@nasa.gov; Rosemary Rochford* - rochforr@upstate.edu

* Corresponding author
\end{abstract}

Published: 18 November 2008

Malaria Journal 2008, 7:238 doi:10.1 186/1475-2875-7-238
Received: 21 July 2008

Accepted: 18 November 2008

This article is available from: http://www.malariajournal.com/content/7/I/238

(c) 2008 Asito et al; licensee BioMed Central Ltd.

This is an Open Access article distributed under the terms of the Creative Commons Attribution License (http://creativecommons.org/licenses/by/2.0), which permits unrestricted use, distribution, and reproduction in any medium, provided the original work is properly cited.

\begin{abstract}
Background: The effects of Plasmodium falciparum on B-cell homeostasis have not been well characterized. This study investigated whether an episode of acute malaria in young children results in changes in the peripheral B cell phenotype.

Methods: Using flow-cytofluorimetric analysis, the B cell phenotypes found in the peripheral blood of children aged 2-5 years were characterized during an episode of acute uncomplicated clinical malaria and four weeks post-recovery and in healthy age-matched controls.

Results: There was a significant decrease in $\mathrm{CD} / 9^{+} \mathrm{B}$ lymphocytes during acute malaria. Characterization of the $\mathrm{CD} / 9^{+} \mathrm{B}$ cell subsets in the peripheral blood based on expression of $\mathrm{IgD}$ and $C D 38$ revealed a significant decrease in the numbers of naive $I C D 38-\operatorname{lgD}{ }^{+} B$ cells while there was an increase in $C D 38^{+} \mid g D$ - memory 3 B cells during acute malaria. Further analysis of the peripheral $B$ cell phenotype also identified an expansion of transitional $C D I 0^{+} C D / 9^{+} B$ cells in children following an episode of acute malaria with up to $25 \%$ of total $C D \mid 9^{+}$B cell pool residing in this subset.
\end{abstract}

Conclusion: Children experiencing an episode of acute uncomplicated clinical malaria experienced profound disturbances in B cell homeostasis.

\section{Background}

There are over 500 million episodes of clinical Plasmodium falciparum malaria annually [1]. The primary burden of infections with $P$. falciparum occurs mainly in children under five years of age living in the tropical and sub-tropical areas of the world, where malaria transmission is holoendemic $[2,3]$. Malaria induces many pathophysiological changes including alterations in both $\mathrm{T}$ and $\mathrm{B}$ cell immunity [4]. In addition, in regions where malaria transmission is holoendemic, immunity is not acquired until after several years of exposure and can be lost rapidly following migration out of a malaria endemic region sug- 
gesting poor generation of protective immune memory [5-7]. The mechanism of immune suppression induced by $P$. falciparum remains an important question to solve in order to achieve protective immunity by means of vaccination.

A number of observations clearly indicate that B cells are affected by $P$. falciparum infection. Hypergammaglobulinaemia has been a well-described feature of Plasmodium infections [8] and persons living in malaria holoendemic regions have elevated total antibody levels [9]. Dorfman $e t$ al [10] reported a diminished frequency of $P$. falciparumspecific memory B cells as indicated by loss of $P$. falciparum antibodies, and Kassa et al [11] reported a decline in total numbers of CD19+ B cells. Polyclonal B cell activation induced by $P$. falciparum [9] most likely occurs through antigenic activation by the cysteine-rich interdomain region $\alpha($ CIDR $1 \alpha)$ of $P$. falciparum erythrocyte membrane protein 1(PfEMP1) and merozoite antigens [12].

In addition to disturbances in generation and maintenance of B cell immunity following $P$. falciparum infection, chronic antigenic activation of $\mathrm{B}$ cells within the context of repeated $P$. falciparum infections may lead to cytogenic abnormalities or aberrations in B cell development and trafficking. This may be one possible explanation for the increased risk for Burkitt's lymphoma in children living in malaria endemic settings [13].

Although there is some data on the types and frequencies of mature $\mathrm{B}$ cells that populate the peripheral blood in healthy children and HIV infected children [14], few studies have examined these changes in B cell subsets as they occur in peripheral blood of children in malaria endemic regions, who bear the burden of malaria related mortality and morbidity. Kassa et al [11] found a decrease in total CD19+ B cells following acute P. falciparum and P. vivax infections, but no further phenotyping of $B$ cell subsets was done. Recent development in B cell biology allow distinctions of peripheral B cells into distinct subsets i.e. naive $\left(\mathrm{CD} 19^{+} \mathrm{IgD}^{+}\right)$and memory $\left(\mathrm{CD} 19^{+} \mathrm{IgD}^{-}\right)$subsets based on IgD staining [15]. Further delineation of peripheral B cells was reported by Bonhorst et al [15]. They used relative levels on IgD and CD38 expression to identify four different $B$ cell sub-populations in peripheral blood. Other markers to delineate peripheral B cell subsets include CD10, which was initially thought to be a marker for germinal center B cells and Burkitt lymphoma cells $[16,17]$. However, CD10 was recently shown to be expressed on a subset of peripheral B cells known as immature transitional B cells $[18,19]$. Infection with HIV was shown to increase $\mathrm{CD} 10^{+} \mathrm{CD} 19^{+}$immature transitional $\mathrm{B}$ cells suggesting that the transitional $\mathrm{B}$ cells are potential marker of inflammation. Whether P. falciparum infection induces these cells is unknown.

To understand how $P$. falciparum infection modulates B cell homeostasis, flow cytofluorimetric (FCF) analysis was used to quantify the percentage of total B cells (CD19+) and to discriminate $\mathrm{B}$ cell subsets in the peripheral blood in children experiencing an acute clinical case of $P$. falciparum malaria and four weeks following recovery. In this study, it was shown that following acute clinical $P$. falciparum malaria there were significant increases in $\mathrm{CD} 10^{+} \mathrm{B}$ cells as well as a decline in CD19+IgD-CD38- population of memory B cells.

\section{Methods \\ Study area}

This study was carried out at Chulaimbo Rural Training Center during the months of June and July 2003. This clinic serves a malaria holoendemic area [13] and is located $25 \mathrm{~km}$ from Kisumu City in Nyanza Province, Western Kenya. Falciparum malaria accounts for $98 \%$ of malarial infections in this region.

\section{Study participants}

All the protocols used in this study were reviewed and approved by the Kenya Medical Research Institute (KEMRI) Ethical Review Committee and Institutional Review Board of Human Studies at University Hospitals of Cleveland, Case Western Reserve University, USA. After informed consent was obtained from the parents or guardians, twenty-five children aged 2-6 years presenting with acute clinical malaria (based on clinical signs determined by a clinical officer) were enrolled in the study. All malaria cases were treated according to the Kenyan national malaria treatment policy set in 1998 which using sulphadoxine-pyrimethamine (SP) as the first-line antimalaria treatment. Inclusion criteria for children in the study included parental/guardians consent for blood samples to be drawn twice within four weeks, age two to six years, and admission with a diagnosis of acute malaria morbidity as defined by an axillary temperature $\geq 37.5^{\circ} \mathrm{C}$ and $P$. falciparum parasitaemia $\geq 5,000$ parasites $/ \mu$ l. Children were excluded from the study if they were severely immunosuppressed, malnourished, or had other concurrent infections that may cause fever such as lower respiratory tract infection; had haemoglobin ( $\mathrm{Hb})$ less than $5 \mathrm{~g} /$ $\mathrm{dl}$; and parasitaemia with fever at the follow-up visit four weeks after enrollment in this study or relocation from study area. Follow-up was conducted four weeks postrecovery. Fifteen children met the inclusion criteria and were further analysed. Ten children were excluded from the study at follow-up based on the exclusion criteria (e.g. relocation from study area, parasitaemia with fever at the follow-up, and $\mathrm{Hb}$ levels needing transfusion between enrollment and follow-up). Eleven healthy-age matched 
children who were parasitaemic, but asymptomatic, and from the same geographic area were included as controls. The clinical and the demographic data of the study participants are displayed in Table 1.

\section{Blood collection}

After measurements of haemoglobin levels using a portable B-haemoglobin photometer (Hemocue AB Angelholm, Sweden), thick and thin blood films were prepared from finger prick samples and stained with $5 \%$ Giemsa to determine Plasmodium species and level of parasitaemia. Following microscopic confirmation of $P$. falciparum parasitaemia of sufficient density, 2-5 $\mathrm{ml}$ of blood whole blood was collected in EDTA vacutainer by venipuncture.

\section{Lymphocyte isolation and cryopreservation}

Blood was anticoagulated in EDTA and peripheral blood mononuclear cells (PBMC) were separated from whole blood by Ficoll-Hypaque density gradient centrifugation within two hours of venipuncture. Cell viability was determined using the trypan blue dye exclusion assay. Cells were resuspended in $1 \mathrm{ml}$ of freezing media (50\% foetal bovine serum, $40 \% \mathrm{RPMI}$, and $10 \% \mathrm{DMSO}$ ) and stored at $-80^{\circ} \mathrm{C}$ for later batch analysis by flow cytometry.

\section{Immunophenotyping of peripheral blood lymphocytes}

Cryropreserved peripheral blood mononuclear cells were quickly thawed in a water bath at $37^{\circ} \mathrm{C}$, washed in cold PBS with $3 \%$ BSA and $10 \mathrm{mM}$ HEPES. PBMC were enumerated using a heamocytometer, and viability routinely assessed to be above $90 \%$. A total of $3 \times 10^{5}$ cells/ $100 \mu \mathrm{l}$ flow buffer (PBS, 3\% BSA) were stained on ice with the following antibodies to lymphocyte surface receptors: CD3-FITC, CD8-FITC, IgD-FITC, CD38-FITC, CD19-PE, CD4-PE, CD38-PE, CD-10PE, CD23-PE, CD45-APC, CD3-APC, and CD19-APC (BD Pharmingen, CA, San Diego, USA). Isotype controls were $\operatorname{IgG}_{2 \mathrm{a}^{\prime}} \mathrm{K}$-FITC (mouse), IgG 1 , K -PE (mouse) and IgG $_{1}$, K -FITC (mouse) (BD Pharmingen). After staining, cells were fixed with $1 \%$ paraformaldehyde for 15 minutes, and then resuspended in $300 \mu \mathrm{l}$ flow buffer for analysis on a FACS Calibur flow cytometer (Becton Dickinson Immunocytometry Systems, San Jose, USA). Data was analysed using CellQuestPro software (BD Immunocytometry Systems).

\section{Immunoglobulin assays}

Total immunoglobulin (IgG, IgM and IgA) was measured using standard capture and detection sandwich enzyme linked immunosorbent assay (ELISA) [20]. The plates were read on an automated OpsysMR microplate reader at 410 nm (DYNEX Technologies, USA). Immunoglobulin concentration were determined by extrapolation from the standard curves.

\section{Statistical analysis}

Paired T-test was used to compare the differences in means of the same individuals at different time points (clinical patients, acute versus post-recovery). Independent-measures T-test was used to compare differences between acute clinical patients, post-recovery and an agematched control group. Heterogeneity of variance assumptions was tested by the Levene statistic. In all cases $\mathrm{P}<0.05$ were considered statistically significant. SPSS v16 (SPSS, Inc., Chicago, IL) was used for statistical analysis.

\section{Results}

\section{General characteristics of the study population}

Twenty-five children presenting with acute clinical malaria were enrolled in this study. However, during follow-up conducted four weeks post recovery, only fifteen children met enrollment criteria and were included in the subsequent analysis. Clinical characteristics of the study participants are shown in Table 1. The mean age of the enrollees was 42.4 months, while controls were 42.8 months. Children presenting with acute uncomplicated clinical malaria had a mean $P$. falciparum parasite density/ $\mu \mathrm{l}$ of $47,066 \pm 32,105$. Four weeks following treatment for malaria, the parasite density had dropped in all cases with a mean density of 3,464 parasites/ $\mu$ l. Some of the controls were asymptomatic, but parasitaemic and had a mean density of 1,820 parasites/ $\mu$ l. Children who had acute clinical malaria had the highest temperature (mean of $37.8^{\circ} \mathrm{C}$ ), whereas during recovery they had comparable temperature to the control children (mean of $36.5^{\circ} \mathrm{C}$ ). The haemoglobin levels were $8.6 \mathrm{~g} / \mathrm{dL}, 10.3 \mathrm{~g} / \mathrm{dL}$, and $10.7 \mathrm{~g} / \mathrm{dL}$ for acute clinical malaria, post-recovery and controls respectively.

Table I: General clinical characteristics of the study subject

\begin{tabular}{lllc}
\hline Study participant status & Acute clinical malaria, $\mathbf{n}=\mathbf{~ I 5}$ & Post recovery, $\mathbf{n}=\mathbf{~ I 5}$ & Controls, $\mathbf{n}=\mathbf{~ I ~ I ~}$ \\
\hline Temperature $\left({ }^{\circ} \mathrm{C}\right)[$ range] & $37.8^{*}[37.5-39.9]$ & $36.5[34.9-37.3]$ & $36.3[35.4-36.8]$ \\
Hemoglobin levels $(\mathrm{g} / \mathrm{dl})[$ range] & $8.6[6.5-12.4]$ & $10.3[6.2-14.0]$ & $10.67[8.6-11.6]$ \\
Parasite density/ $\mu \mathrm{l}[$ range] & $47066[\mathrm{I}|280-14| 960]$ & $3464[0-18280]$ & $1820[680-3000]$ \\
\hline
\end{tabular}

*Values are arithmetic mean of the variables assessed in the three clinical groups 


\section{Changes in $\mathrm{CD} 19^{+} \mathrm{B}$ cells in children with acute clinical malaria}

Since acute clinical malaria has been associated with perturbation of lymphocyte populations [11,21], the frequency of $\mathrm{T}$ and $\mathrm{B}$ cells in peripheral blood of children was first examined during acute clinical malaria and postrecovery. These values were then compared with $\mathrm{T}$ and $\mathrm{B}$ cell frequencies in healthy age-matched controls. Following recovery from malaria, children had a significantly higher percentage of CD19+ B cells relative to when they had an episode of acute clinical malaria $(P=0.02)$ (Table 2 ). In contrast, no significant differences in $\mathrm{CD} 3^{+} \mathrm{T}$ cells were observed in the same children during acute versus recovery phases of malaria. To further delineate the T cell subsets, the percentage of $\mathrm{CD}^{+}{ }^{+} \mathrm{CD} 4{ }^{+}$and $\mathrm{CD} 3+\mathrm{CD} 8+$ cells in the same samples was analyzed. While no significant differences were observed in the percentages of $\mathrm{CD}^{+}$ and $\mathrm{CD}^{+}$cells between children with acute malaria and following recovery, significantly fewer $\mathrm{CD} 3{ }^{+} \mathrm{CD} 4{ }^{+}$cells $(\mathrm{P}$ $=0.04)$ and more $\mathrm{CD} 3+\mathrm{CD} 8+\mathrm{T}$ cells $(\mathrm{P}=0.03)$ were measured in healthy age-matched controls relative to the children that had recovered from acute malaria.

\section{Alterations in memory and naive B cell subsets in children with acute clinical malaria}

Four major populations of B cells in the peripheral blood can be distinguished based on expression of $\operatorname{IgD}$ and CD38 [15]: naive $1\left(\mathrm{CD}_{38} \mathrm{IgD}^{+}\right)$, naive $2\left(\mathrm{CD}^{+}{ }^{+} \mathrm{IgD}^{+}\right)$, memory 3 (CD38+IgD $)$ and memory 4 (CD38-IgD-). To determine the frequencies of these $\mathrm{B}$ cell subsets in the study population, PBMC were live-gated on CD19+ cells to collect sufficient number of cells for analysis and then analysed for expression of IgD and CD38. A representative FCF analysis is shown in Figure 1A and results for all samples are reported in Table 2. Children with acute clinical malaria had significantly lower naive 1 (CD38-IgD $\left.{ }^{+}\right)$B cell subsets compared to the same population following recovery $(P=0.03)$ and to age-matched healthy controls $(P=0.00)$. In contrast, elevation of the memory 3 (CD38 $\left.{ }^{+} \mathrm{IgD}^{-}\right) \mathrm{B}$ cell subset was observed in the acute clinical malaria compared to the same population following recovery $(\mathrm{P}=0.00)$ and to age-matched healthy controls $(P=0.01)$. Interestingly, the memory 4 (CD38-IgD-) B cell subset was significantly lower in both acute clinical malaria and recovery compared to healthy controls $(\mathrm{P}=$ 0.01 and $P=0.00$ respectively). This mirrors the increase in the naive $2(\mathrm{CD} 38+\mathrm{IgD}+) \mathrm{B}$ cell subset during both acute clinical malaria and recovery compared to healthy controls ( $\mathrm{P}=0.04$ and $\mathrm{P}=0.01$ respectively).

\section{Falciparum malaria results in increases in transitional $C D 19^{+} C D / 0^{+} B$ cells in peripheral blood}

CD10 was originally thought to be expressed primarily by germinal center B cells and Burkitt's lymphoma tumor cells [17]. However, recently CD10 expression has been associated with immature transitional B cells [18,19]. To determine whether acute clinical $P$. falciparum induces increased expression of CD10, phenotypic analysis of peripheral blood of children during acute clinical malaria, following recovery and in asymptomatic children was per-

Table 2: Mean percentage of lymphocyte subsets at presentation with acute non-complicated malaria, 4 weeks post-recovery and in healthy age-matched controls

\begin{tabular}{|c|c|c|c|c|c|c|c|c|c|}
\hline \multirow{3}{*}{$\begin{array}{l}\text { Cell type } \\
\text { CD3 }^{+}{ }^{+} \text {CD } 45^{+}\end{array}$} & \multicolumn{2}{|c|}{$\begin{array}{l}\text { Acute } \\
\text { (A) }\end{array}$} & \multicolumn{2}{|c|}{$\begin{array}{l}\text { Recovery } \\
\text { (R) }\end{array}$} & \multicolumn{2}{|c|}{$\begin{array}{l}\text { Controls } \\
\text { (C) }\end{array}$} & \multicolumn{3}{|c|}{ Significance } \\
\hline & \multicolumn{2}{|c|}{$\begin{array}{l}\text { mean }(\mathrm{SEM}) \\
\text { percent }\end{array}$} & \multicolumn{2}{|c|}{$\begin{array}{l}\text { mean (SEM) } \\
\text { percent }\end{array}$} & \multicolumn{2}{|c|}{$\begin{array}{l}\text { mean (SEM) } \\
\text { percent }\end{array}$} & \multirow{2}{*}{$\begin{array}{c}\text { A vs.R } \\
0.37\end{array}$} & \multirow{2}{*}{$\begin{array}{c}\text { A vs. C } \\
0.27\end{array}$} & \multirow{2}{*}{$\begin{array}{r}\text { R vs.C } \\
0.67\end{array}$} \\
\hline & 56.9 & $(2.4)$ & 54.3 & $(2.3)$ & 52.7 & $(2.7)$ & & & \\
\hline $\mathrm{CD} 19^{+} \mathrm{CD} 45^{+}$ & 21.4 & $(2.1)$ & 26.1 & (1.7) & 23.5 & $(2.8)$ & 0.02 & 0.53 & 0.41 \\
\hline $\mathrm{CD}^{+}{ }^{+} \mathrm{CD}^{+}+$ & 34.8 & (2.6) & 36.0 & (2.2) & 29.4 & (1.9) & 0.64 & 0.14 & 0.04 \\
\hline $\mathrm{CD}^{+}{ }^{+} \mathrm{CD} 3^{+}$ & 16.0 & (2.5) & 12.8 & (1.2) & 18.2 & $(0.8)$ & 0.22 & 0.62 & 0.03 \\
\hline $\begin{array}{l}\text { Naive I } \\
\text { CD38-lgD+CD 19+ }\end{array}$ & 23.7 & $(2.9)$ & 29.3 & $(4.2)$ & 38.2 & (3.4) & 0.03 & 0.00 & 0.12 \\
\hline $\begin{array}{l}\text { Naive } 2 \\
\text { CD } 38^{+} \lg D^{+} \mathrm{CD} 19^{+}\end{array}$ & 39.7 & (3.8) & 44.7 & (4.4) & 27.2 & $(4.4)$ & 0.11 & 0.04 & 0.01 \\
\hline $\begin{array}{l}\text { Memory } 3 \\
\text { CD38+IgD-CD19+ }\end{array}$ & 22.7 & (2.4) & 14.4 & $(1.3)$ & 14.2 & $(1.1)$ & 0.00 & 0.01 & 0.91 \\
\hline $\begin{array}{l}\text { Memory } 4 \\
\text { CD38-lgD-CD19+ }\end{array}$ & 13.5 & (1.4) & 11.7 & $(1.3)$ & 22.8 & $(2.6)$ & 0.11 & 0.01 & 0.00 \\
\hline $\mathrm{CDIO}^{+} \mathrm{CD} / 9^{+}$ & 24.6 & $(2.5)$ & 29.0 & $(2.7)$ & 21.2 & $(1.8)$ & 0.04 & 0.31 & 0.04 \\
\hline
\end{tabular}

Sample size $(n)$ was $n=15$ for all Acute \& Recovery outcomes except CDI9+CDI0+ $(n=12)$, and all Memory and Naive outcomes $(n=11)$. $N=$

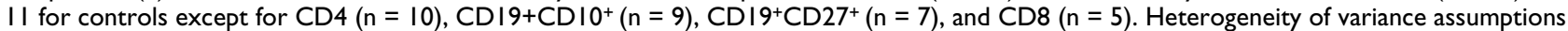
were tested by the Levene statistic, and heterogeneous t-tests were utilized as needed. Significant differences are in bold. 


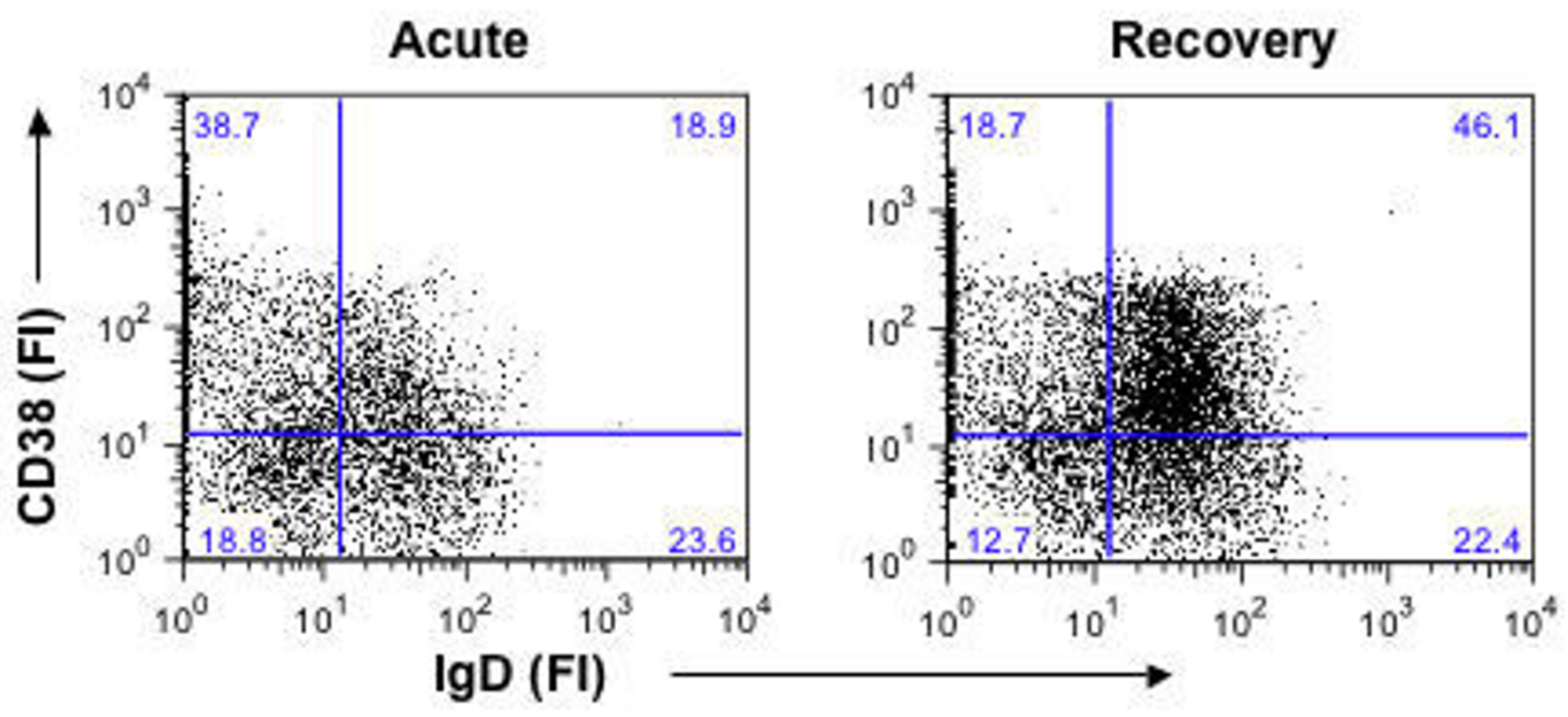

Figure I

Alterations in peripheral B cell subsets in children with acute malaria compared to the same children following recovery. Representative FCF analysis of CDI9+ $B$ cells stained for CD38 and IgD. Expression of CD38 and IgD can be used to identify naive and memory $B$ cell subpopulations in the peripheral blood [I5].

formed. The results illustrate that following recovery from malaria, children had significantly higher levels of CD10 expression than during acute clinical malaria $(\mathrm{P}=0.04)$ and also compared to controls $(\mathrm{P}=.04)$ (Table 2$)$. Importantly, it was confirmed that the peripheral B cells expressing CD10 were negative for CD34 or CD27.

\section{Acute clinical malaria results in hypergammaglobulinaemia}

Previous studies have demonstrated that acute clinical malaria is associated with hypergammaglobulinaemia [8]. To determine if this was also true for these study participants, quantitative total immunoglobins (Ig) were measured using ELISA in the plasma obtained from PBMC. As shown in Figure 2, increased levels of total Ig were evident during acute clinical malaria, with children having significantly higher Ig levels during acute clinical malaria as compared to post recovery $(\mathrm{p}<0.005)$ and the controls $(\mathrm{p}<0.001)$. Additionally the Ig levels were significantly higher post recovery as compared to controls ( $\mathrm{p}<$ 0.05).

\section{Discussion}

Although extensive information is available on the types and frequencies of mature $B$ cells that populate the peripheral blood, few studies have been done analysing how B-cell lymphopoiesis is altered in children infected

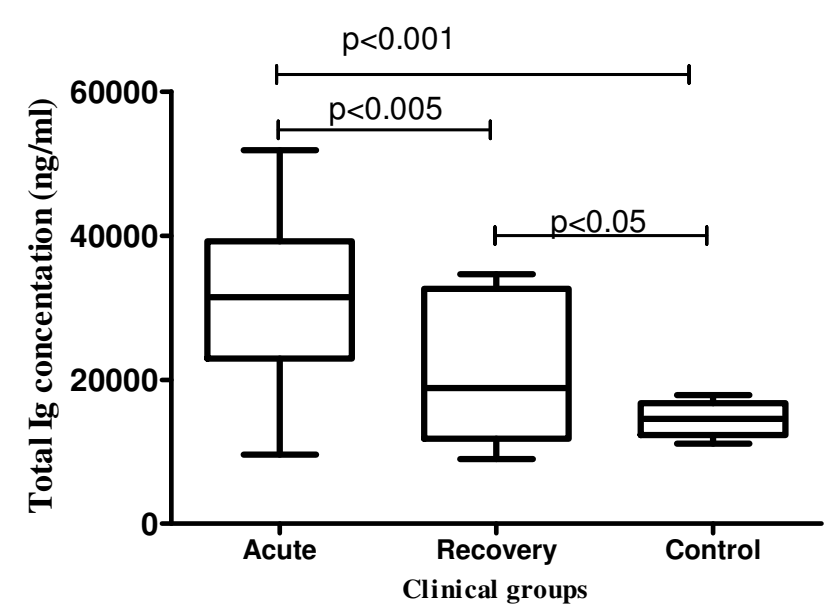

Figure 2

Comparison of serum Ig levels in children with acute malaria, following recovery and age-matched controls. Total human Ig (IgG, $\lg M$ and $\lg A)$ in plasma was determined by ELISA analysis. Shown are mean (SEM) Ig levels between children with acute malaria $(n=15)$, the same children following recovery and age matched healthy children ( $\mathrm{n}$ $=6)$. Significant differences between acute $(a)$, recovery $(r)$, and controls (c) as noted. 
with $P$. falciparum malaria. In this study, a significant decline in the percentages of CD19+ B cells in the peripheral blood of children during an episode of acute clinical $P$. falciparum malaria compared to the same children postrecovery and to healthy age-matched children was observed. In addition, the children with acute malaria had an increase in a memory B cell subset and a concomitant decrease in a naive $B$ cell subset in children as compared to the same children post-recovery and to healthy agematched children. Thus, the data presented here suggests that $P$. falciparum infection results in perturbations of the B cell compartment and is consistent with accumulating evidence from a number of other studies showing dysregulation of B cell function following $P$. falciparum infection $[11,21]$.

Lymphopaenia has long been recognized as a complication of acute malaria [22]. Consistent with this, there was a decline in percentages of $\mathrm{CD} 19^{+} \mathrm{B}$ cells during acute malaria in this study. However, there were no significant differences in $\mathrm{CD}^{+} \mathrm{T}$ cells in this same population. Although the immunological pathways that orchestrate $\mathrm{B}$ lymphocyte depletion are unknown, $P$. falciparum malaria may interfere with B cell lymphopoiesis, induce lymphocyte apoptosis as shown following infection of macaques with $P$. coatneyi [23], or result in sequestration of lymphocytes to other tissues or endothelium [22]. Lastly, given the hypergammaglobulinaemia that this study and others [8] have observed following $P$. falciparum infection, the possibility exists that $P$. falciparum infection, possibly through direct interactions of $P$. falciparum antigens with memory B cells, is driving memory B cells towards plasma cell differentiation and migration of these cells back to the bone marrow. Consistent with this, changes in B cell subsets were observed, with significantly higher memory $3 \mathrm{~B}$ cell subset observed in acute clinical malaria compared to recovery or controls, and a lower percent of memory $4 \mathrm{~B}$ cell subset in children both during acute and following recovery compared to healthy agematched controls. Taken together, these observations have important implications in the maintenance of immunologic memory to vaccine antigens in populations chronically exposed to malaria infections, especially in children since they are most vulnerable to this parasitic infection.

Elevated levels of the $\mathrm{IgD}^{+} \mathrm{CD} 38^{+}$naive 2 equivalent of pre-germinal center $\mathrm{B}$ cells have been reported in the peripheral blood children with systemic lupus erythematosus [24], but this B cell subset is rarely observed in peripheral blood of healthy individuals. This study also reported elevated levels of these pre-germinal center $\mathrm{B}$ cells in children following recovery from acute clinical malaria. It is unclear whether this reflects interference of $P$. falciparum infection with B cell trafficking and/or differ- entiation, which could lead to cells exiting secondary lymphoid organs at early differentiation stages. A recent report found that the architecture of the germinal center was disrupted in a mouse model of malaria [25]. Furthermore, Urban and colleagues also observed disruption of splenic organization in autopsy studies of adults who died of $P$. falciparum malaria [26]. Together, these studies point towards $P$. facliparum infection resulting in alterations of lymphoid architecture, which could result in the changes in peripheral B cell subsets that were observed in this study.

An expansion of CD10+CD19+ B cells was observed following recovery from acute clinical $P$. falciparum malaria, with up to $25 \%$ of total CD $19+$ B cell pool residing in this subset. The cells expressing CD10 cells were $\mathrm{IgD}^{+}$and $\mathrm{CD}^{2} 4^{-}$, suggesting that they were not pre-B cells that had aberrantly migrated to the periphery from the bone marrow $[27,28]$. Studies in autoimmune and immunodeficiency diseases have associated the expression of CD10 with immature transitional B cells and their elevated levels in peripheral circulation are thought to be indicative of B cell dysfunction [18]. Interestingly, Burkitt lymphoma express CD10 and it this has led to the idea that these tumors may be derived from $\mathrm{CD} 10^{+}$germinal center $\mathrm{B}$ cells [17]. It is possible that $P$. falciparum infection induces immature B cells to leave the bone marrow at an earlier differentiation stage $[15,19]$, and thereby increase proliferation of $B$ cell subsets that are precursors of eBL. This may explain the increased risk for Burkitt's lymphoma in children living in malaria holoendemic regions.

The methods for determining the percentage of lymphocyte subsets in peripheral blood have over time, switched from PBMC isolation and then phenotyping to direct phenotyping from whole blood. The phenotype of peripheral blood lymphocytes was analysed following isolation of PBMC because of the difficulties in timing when samples were collected, the desire to do a batch analysis on all the samples to ensure consistency in our analysis, and the inherent challenges of the clinical setting in Kenya in which we were working. There are very few published studies of lymphocyte subsets in healthy children and most are based on children living in developed countries. The present study observed that the mean CD $19+\mathrm{B}$ cells as a percentage of CD $45^{+}$lymphocytes was $23.53 \%$ in healthy controls. This is within the range reported in healthy children and HIV infected children and is much higher than observed in healthy adults where the range is typically $12 \%$ of total lymphocytes [14]. The present study also reported higher levels of CD10+CD19+ $\mathrm{B}$ cells than reported for one other study examining CD10+ levels in HIV infected children [14]. 


\section{Conclusion}

In summary, these results demonstrate that during acute uncomplicated episodes of $P$. falciparum malaria in children, there were major perturbations in B cell subsets including a decline in memory $\mathrm{B}$ cells and an increase in transitional CD $10^{+}$cells. Understanding the mechanisms underlying the alterations in B cell lymphopoeisis are needed to aid in vaccine development.

\section{Competing interests}

The authors declare that they have no competing interests.

\section{Authors' contributions}

ASA carried out the cell isolation, cell analysis and drafted the manuscript. AMM participated in the design and coordination of the study and draft of manuscript. CK participated in recruitment, FCF analysis and draft of manuscript. ZWN participated in study design. RPS carried out the statistical analysis. RR conceived of the study, and participated in its design and coordination and helped to draft the manuscript. All authors read and approved the final manuscript.

\section{Acknowledgements}

This work was done with the permission of the Director of the Kenya Medical Research Institute. The authors thank the field assistants and the families for their participation in this study and Dr. Erwan Piriou for critical reading of the manuscript. The authors thank Bob Balderas (BD-Pharmingen Inc., La Jolla, CA) for generous donation of antibodies for this study. This work was supported by NIH R0I CAI 02667 (R.R.), NIH K08 AI 5 I 565 (A.M.), and the Elizabeth Crosby Award (R.R.)

\section{References}

I. Snow RW, Guerra CA, Noor AM, Myint HY, Hay SI: The global distribution of clinical episodes of Plasmodium falciparum malaria. Nature 2005, 434:2/4-217.

2. Guerra CA, Snow RW, Hay SI: Mapping the global extent of malaria in 2005. Trends Parasitol 2006, 22:353-358.

3. Rowe AK, Rowe SY, Snow RW, Korenromp EL, Schellenberg JR, Stein C, Nahlen BL, Bryce J, Black RE, Steketee RW: The burden of malaria mortality among African children in the year 2000. Int J Epidemiol 2006, 35:69I-704.

4. Artavanis-Tsakonas K, Tongren JE, Riley EM: The war between the malaria parasite and the immune system: immunity, immunoregulation and immunopathology. Clin Exp Immunol 2003, 133:145-152.

5. Marsh K, Otoo L, Hayes RJ, Carson DC, Greenwood BM: Antibodies to blood stage antigens of Plasmodium falciparum in rural Gambians and their relation to protection against infection. Trans R Soc Trop Med Hyg 1989, 83:293-303.

6. Giha HA, Staalsoe T, Dodoo D, Elhassan IM, Roper C, Satti GM, Arnot DE, Theander TG, Hviid L: Nine-year longitudinal study of antibodies to variant antigens on the surface of Plasmodium falciparum -infected erythrocytes. Infect Immun 1999, 67:4092-4098.

7. Cavanagh DR, Elhassan IM, Roper C, Robinson VJ, Giha H, Holder AA, Hviid L, Theander TG, Arnot DE, McBride JS: A longitudinal study of type-specific antibody responses to Plasmodium falciparum merozoite surface protein- $I$ in an area of unstable malaria in Sudan. J Immunol 1998, 161:347-359.

8. Greenwood BM: Possible role of a B-cell mitogen in hypergammaglobulinaemia in malaria and trypanosomiasis. Lancet 1974, I:435-436.

9. Whittle HC, Brown J, Marsh K, Blackman M, Jobe O, Shenton F: The effects of Plasmodium falciparum malaria on immune control of B lymphocytes in Gambian children. Clin Exp Immunol 1990 , $80: 213-2 \mid 8$

10. Dorfman JR, Bejon P, Ndungu FM, Langhorne J, Kortok MM, Lowe BS, Mwangi TW, Williams TN, Marsh K: B cell memory to 3 Plasmodium falciparum blood-stage antigens in a malaria-endemic area. J Infect Dis 2005, 191:1623-1630.

II. Kassa D, Petros B, Mesele T, Hailu E, Wolday D: Characterization of peripheral blood lymphocyte subsets in patients with acute Plasmodium falciparum and $P$. vivax malaria infections at Wonji Sugar Estate, Ethiopia. Clin Vaccine Immunol 2006, 13:376-379.

12. Donati D, Espmark E, Kironde F, Mbidde EK, Kamya M, Lundkvist A, Wahlgren M, Bejarano MT, Falk KI: Clearance of circulating Epstein-Barr virus DNA in children with acute malaria after antimalaria treatment. J Infect Dis 2006, 193:97I-977.

13. Rainey JJ, Mwanda WO, Wairiumu P, Moormann AM, Wilson ML, Rochford R: Spatial distribution of Burkitt's lymphoma in Kenya and association with malaria risk. Trop Med Int Health 2007, 1 2:936-943.

14. Ibegbu C, Spira TJ, Nesheim S, Mendez H, Lee F, Polliotti B, Caba J, Nahmias A: Subpopulations of T and B cells in perinatally HIVinfected and noninfected age-matched children compared with those in adults. Clin Immunol Immunopathol 1994, 71:27-32.

15. Bohnhorst JO, Bjorgan MB, Thoen JE, Natvig JB, Thompson KM: Bm I-Bm5 classification of peripheral blood $B$ cells reveals circulating germinal center founder cells in healthy individuals and disturbance in the $B$ cell subpopulations in patients with primary Sjogren's syndrome. J Immunol 200I, 167:3610-3618.

16. Shaffer AL, Rosenwald A, Staudt LM: Lymphoid malignancies: the dark side of B-cell differentiation. Nat Rev Immunol 2002, 2:920-932.

17. Rowe M, Rowe DT, Gregory CD, Young LS, Farrell PJ, Rupani H, Rickinson $A B$ : Differences in $B$ cell growth phenotype reflect novel patterns of Epstein-Barr virus latent gene expression in Burkitt's lymphoma cells. EMBO J 1987, 6:2743-275I.

18. Sims GP, Ettinger R, Shirota Y, Yarboro CH, Illei GG, Lipsky PE: Identification and characterization of circulating human transitional B cells. Blood 2005, 105:4390-4398.

19. Malaspina A, Moir S, Ho J, Wang W, Howell ML, O'Shea MA, Roby GA, Rehm CA, Mican JM, Chun TW, Fauci AS: Appearance of immature/transitional B cells in HIV-infected individuals with advanced disease: correlation with increased IL-7. Proc Natl Acad Sci USA 2006, 103:2262-2267.

20. Rochford R, Hobbs MV, Garnier J-L, Cooper NR, Cannon MJ: Plasmacytoid differentiation of Epstein-Barr virus-transformed B cells in vivo is associated with reduced expression of viral latent genes. Proc Natl Acad Sci, USA 1993, 90:352-356.

21. Worku S, Bjorkman A, Troye-Blomberg M, Jemaneh L, Farnert A, Christensson B: Lymphocyte activation and subset redistribution in the peripheral blood in acute malaria illness: distinct gammadelta+ $T$ cell patterns in Plasmodium falciparum and P. vivax infections. Clin Exp Immunol 1997, 108:34-4I.

22. Elhassan IM, Hviid L, Satti G, Akerstrom B, Jakobsen PH, Jensen JB, Theander TG: Evidence of endothelial inflammation, $T$ cell activation, and $\mathrm{T}$ cell reallocation in uncomplicated Plasmodium falciparum malaria. Am J Trop Med Hyg 1994, 5 I:372-379.

23. Matsumoto J, Kawai S, Terao K, Kirinoki M, Yasutomi Y, Aikawa M, Matsuda $\mathrm{H}$ : Malaria infection induces rapid elevation of the soluble Fas ligand level in serum and subsequent $T$ lymphocytopenia: possible factors responsible for the differences in susceptibility of two species of Macaca monkeys to Plasmodium coatneyi infection. Infect Immun 2000, 68: I I 83-I I 88.

24. Arce E, Jackson DG, Gill MA, Bennett LB, Banchereau J, Pascual V: Increased frequency of pre-germinal center $B$ cells and plasma cell precursors in the blood of children with systemic lupus erythematosus. J Immunol 200I, 167:236I-2369.

25. Carvalho LJ, Ferreira-da-Cruz MF, Daniel-Ribeiro CT, Pelajo-Machado $M$, Lenzi HL: Germinal center architecture disturbance during Plasmodium berghei ANKA infection in CBA mice. Malar J 2007, 6:59.

26. Urban BC, Hien TT, Day NP, Phu NH, Roberts R, Pongponratn E, Jones M, Mai NT, Bethell D, Turner GD, Gerguson D, White NJ, Roberts DJ: Fatal Plasmodium falciparum malaria causes specific patterns of splenic architectural disorganization. Infect Immun 2005, 73:1986-1994. 
27. Loken MR, Shah VO, Dattilio KL, Civin Cl: Flow cytometric analysis of human bone marrow. II. Normal B lymphocyte development. Blood 1987, 70:1316-1324.

28. Billips LG, Lassoued K, Nunez C, Wang J, Kubagawa H, Gartland GL, Burrows PD, Cooper MD: Human B-cell development. Ann N Y Acad Sci 1995, 764: I-8.

Publish with Bio Med Central and every scientist can read your work free of charge

"BioMed Central will be the most significant development for disseminating the results of biomedical research in our lifetime. " Sir Paul Nurse, Cancer Research UK

Your research papers will be:

- available free of charge to the entire biomedical community

- peer reviewed and published immediately upon acceptance

- cited in PubMed and archived on PubMed Central

- yours - you keep the copyright

Submit your manuscript here:

http://www.biomedcentral.com/info/publishing_adv.asp 